\title{
PROFESSOR MELVILLE GRAFTON RICHARDS
}

\section{Elected Ist March I962}

Professor Richards died suddenly on 3 rd November 1973 at the age of 63 . His death is a great loss to Welsh scholarship. Educated at University College, Swansea, his postgraduate work was in the field of medieval Welsh syntax, and he continued his studies in Dublin and Paris. In 1936 he became a lecturer in Welsh at Swansea. He was appointed lecturer, and subsequently reader, in Welsh at the University of Liverpool in 1947, and became Head of its Department of Celtic. In 1965, he was appointed to the Chair of Welsh at the University College of North Wales at Bangor. In addition to his contributions to the study of syntax, he published editions of medieval Welsh texts, and he was also interested in aspects of Welsh legal customs. However, his particular interest was in the study of place-names: he was a member of the English Place-Name Society and had an international reputation for his achievements in this area of scholarship. His publications included Welsh Administrative and Territorial Units: Medieval and Modern (1 g69).

\section{JOHN SALTMARSH, ESQ, M.A.}

\section{Elected Ist March I934}

John Saltmarsh died on 25th September 1974 at the age of 66. He was a distinguished Cambridge historian and antiquary with a particular devotion to King's College. Having gained a First with distinctions in both parts of the Tripos at King's, he was made a Fellow at the age of 22 for his dissertation on the history of the College's estates. He was a teacher and librarian of the College from 1937 to 1947. After the war he returned to King's and in 1958 produced for Volume III of The Victoria County History of Cambridgeshire a history of the College, full of original research. He was subsequently engaged on a history of King's College Chapel, but did not live to complete the work. John Saltmarsh will be remembered particularly for his enthusiastic lectures, his tours of King's College Chapel, and his classes on medieval Cambridge.

\section{MAJOR-GENERAL HARVEY DEGGE WILMOT SITWELL C.B., C.V.O., M.C. \\ Elected 2nd May 1957}

Major-General Harvey Sitwell died on the 28th September 1973 at the age of 76 . He was Keeper of the Jewel House at the Tower of London from 1952 until he retired in 1968 . Not only did he make a detailed study of published material on the Regalia, but he also examined the original documents relating to it, and his investigations produced the final and conclusive evidence for the antiquity of the gold in the present St. Edward's Crown.

Major-General Sitwell's book, The Crown Fewels, was published in 1953. He was also part author of The English Regalia, which traced the history of his own office from the Middle Ages to the present day, and the techniques of displaying the Crown Jewels from the time of King Charles onwards. 